\title{
Trace element concentration in Antarctic krill reflecting their distribution in the Weddell Sea
}

\author{
A. S. Solomatina ${ }^{1}$, L. L. Demina ${ }^{1}$, and V. A. Spiridonov ${ }^{1}$ \\ Received 8 February 2021; accepted 17 February 2021; published 19 July 2021.
}

Distribution of $\mathrm{Al}, \mathrm{As}, \mathrm{Cd}, \mathrm{Co}, \mathrm{Cu}, \mathrm{Fe}, \mathrm{Mn}, \mathrm{Mo}, \mathrm{Ni}, \mathrm{Pb}, \mathrm{Rb}$, and $\mathrm{Zn}$ in the main body parts and total samples of juvenile Antarctic krill Euphausia superba was examined in the northeastern Weddell Sea. The increased contents of Al, Fe, and Mn in total specimens of juvenile krill were detected in the coastal regions near the South Shetland and South Orkney Islands. It can be attributed to high concentration of suspended particulate matter that serve as food for krill both in shallow and deep water. The cephalothorax was found to be an organ of the elevated concentration of $\mathrm{Al}, \mathrm{Zn}, \mathrm{Cu}$, and $\mathrm{Fe}$; Mo accumulated primarily in the abdominal muscles, while $\mathrm{Ni}, \mathrm{Co}, \mathrm{Cd}, \mathrm{As}, \mathrm{Rb}$, and $\mathrm{Pb}$ did not show a predominant accumulation in certain krill tissues. The contents of potentially toxic $\mathrm{Zn}, \mathrm{Cd}, \mathrm{Cu}$, and $\mathrm{Pb}$ in the total krill mass did not exceed the maximum permissible concentration (MPC) for marine seafood products, while that of As was two times greater than the MPC that might be caused by both natural and anthropogenic factors. KEYWORDS: Antarctica; krill Euphausia superba; heavy metals; trace elements; bioaccumulation.

Citation: Solomatina, A. S., L. L. Demina, and V. A. Spiridonov (2021), Trace element concentration in Antarctic krill reflecting their distribution in the Weddell Sea, Russ. J. Earth. Sci., 21, ES4001, doi:10.2205/2021ES000759.

\section{Introduction}

Trace elements play an important role in marine biological processes, such as the chlorophyll synthesis, electron transport during respiration, cell lysis, enzyme synthesis, and activation [Bowen, 1988 . Bruland and Lohan, 2004, Sunda, 1989, etc.]. Most trace elements are known to be accumulated in marine organisms, but exceeding a certain threshold can lead to toxic effects [Fuentes et al., 2016. The trace elements are accumulated in zooplankton to high levels, and zooplankton metabolic activity enhances the biogeochemical cycling of trace elements through the release of particulate matter such as fecal pellets, molted exoskeletons, and eggs [Fowler,

\footnotetext{
${ }^{1}$ Shirshov Institute of Oceanology RAS, Moscow, Russia
}

Copyright 2021 by the Geophysical Center RAS. http://rjes.wdcb.ru/doi/2021ES000759-res.html
1977. Martin and Knauer, 1973. Zooplankton populations that are abundant in the continental margins accumulate large masses of trace elements accelerating the dynamics of their biogenic migration in the shallow water [Demina, 2015. From the viewpoint of sedimentology, zooplankton operates as a second-level global biological pump [Siegel et al., 2007] or biofilter [Lisitsyn, 2004, Monin and Lisitsyn, 1983, which generates the vertical flux of sedimentary material in the pelagic water.

In the Southern Ocean, the ultra-low concentrations of bioavailable forms of trace elements, iron particularly, limit primary production that has been experimentally confirmed [De Baar et al., 1995, Boyd, 2001; Holm-Hansen et al., 2005. Hutchins, 1995. Martin et al., 1990. The Southern Ocean constitutes the largest high-nutrient lowchlorophyll (HNLC) zone in the world [Boyd et al., 2001, Twining and Baines, 2013. Relatively high phytoplankton biomass is restricted to sectors around or downstream of islands, the continen- 
tal shelf, and in the Antarctic Polar Frontal Zone [Holm-Hansen et al., 2005; Sullivan et al., 1993]. In the Weddell Sea, primary production was greatly increased within a radius of up to tens of $\mathrm{km}$ due to the inflows of micronutrients during the melting of giant (over $18 \mathrm{~km}$ long) icebergs [Duprat et al., 2016. The circulation of the Weddell Sea along the eastern continental margin of the Antarctic Peninsula plays an essential role in the export of particulate material from the coast to more open waters [Sanches et al., 2019]. On the other hand, the biogeochemical processes occurring in the Southern Ocean (primary production in surface waters, mineralization of organic carbon at depths, upwelling of carbon-rich water masses) are of fundamental importance for the global climate and the carbon cycle [Fogwill et al., 2020].

The Atlantic sector of the Southern Ocean attracts an attention of researchers from many countries related to international obligations of the Convention for the Conservation of Antarctic Marine Living Resources (CCAMLR) [URL: http://www. ccamlr.org aimed at monitoring quality of the marine environment in this unique area. The Antarctic krill (Euphausia superba) is the most numerous species of Antarctic zooplankton and micronekton. This species having a high biomass, estimated in the range of $10^{7}-10^{8} \mathrm{t}$ [Siegel and Watkins, 2016], plays a fundamental role in the Antarctic food chain [Trathan and Hill, 2016. The krill organisms use various feeding strategies with a large range of captured suspended particles being the consumers of phytoplankton, small zooplankton, ice algae, microbiota, and detritus on the shelves. In turn, krill itself serves as the main diet of larger marine organisms (whales, seals, penguins, etc.), as well as a source of valuable protein in the humans' diet. The krill oil, consisting of a variety of lipid compounds, is characterized by high content (39 to 81\%) of phospholipids and significant amounts of bioactive components, such as antioxidants, sterol, tocopherol, flavonoids, and trace elements [Kawaguchi and Nicol, 2007 that are healthy food for people. Krill is one of the most important objects of fishing because of its high nutritional, technical, and medicinal value, as well as the availability of crustacean clusters for commercial fishing gear [Bykova, 2001 .

The krill habitat is distributed around the entire Antarctic region, but especially important for feeding and replenishment of its populations are the areas of formation of large-scale aggregations confined to the circulation zones of the Southern Ocean with high primary production [Bizikov et al., 2007]. According to hydroacoustic studies, the Weddell Front and Antarctic Slope Front in the Weddell Sea create conditions for the formation of the dense aggregations of krill along its periphery in the areas of the Antarctic Circumpolar Current along the slope of the Antarctic Peninsula, in the Bransfield Strait, and the South Orkney Islands [Sologub, 2015]. Research results of ecology, physiology, distribution patterns of the size and age groups of krill Euphausia superba in the Weddell Front showed that different generations of krill are mostly separated [Bykova, 2001: Spiridonov, 1996.

The features of the trace metal and biochemical composition of the Antarctic krill Euphausia superba were under consideration mostly in the last decades of the of 20-th century. It was found that the concentrations of $\mathrm{Cu}, \mathrm{Zn}, \mathrm{Fe}, \mathrm{Mn}, \mathrm{Ni}, \mathrm{Cd}, \mathrm{Pb}$ and $\mathrm{Hg}$ in total krill samples vary depending on the environmental conditions and exhibiting high values of bioconcentration factor (BCF) up to $2 \times 10^{4}$ ) [Yamamoto et al., 1987]. The significant changes in the krill's body composition (water, ash, protein, chitin, lipids, $\mathrm{Ca}, \mathrm{Sr}, \mathrm{Mg}$, and $\mathrm{Cu}$ ) happen during molting [Nicol et al., 1992. A separate examination of the krill total samples and its heads showed no significant differences in concentrations of heavy metals ( $\mathrm{Cu}, \mathrm{Fe}, \mathrm{Zn}, \mathrm{Cd}, \mathrm{Pb}, \mathrm{Ni}, \mathrm{Cr}, \mathrm{Mn}$ ), as well as $\mathrm{Mg}$ and lipids, while the cholesterol content was three times higher in the whole body compared to the head [Raghunath et al., 2000.

Nevertheless, little data exist on the trace element composition of Antarctic krill collected during the ongoing warming period. Over 2002-2009 years, the high concentrations of $\mathrm{Cd}$ and $\mathrm{Zn}$ in both the krill habitat and their bodies were attributed to leaching these toxicants from the sediments of the mainland and Antarctic islands during the melting of glaciers as a result of climate warming [Samyshev and Minkina, 2019. These authors suggested that a sharp decrease in the stock of Euphausia superba resulted from an inhibition of reproduction of crustaceans, whose eggs develop at the bottom of shallow waters exposed to additional supply of heavy metals.

The goal of this work is to determine concentrations of a number of trace elements including the 


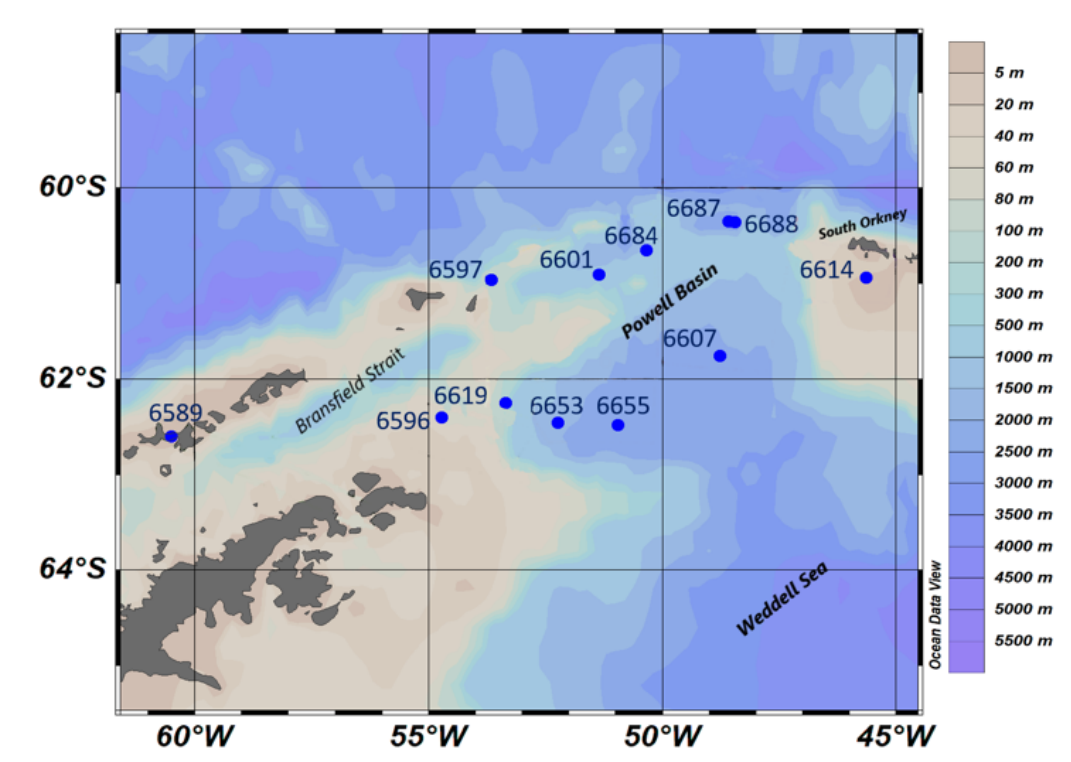

Figure 1. Scheme of stations for sampling Euphausia superba krill, in January-March 2020 in the northwestern Weddell Sea (Powell Basin).

Table 1. Krill Sampling Stations in the Northwestern Weddell Sea

\begin{tabular}{lcccc}
\hline Station & Sampler & Sea depth, $\mathrm{m}$ & \multicolumn{2}{c}{ Location } \\
& & & Latitude, ${ }^{\circ} \mathrm{S}$ & Longitude, ${ }^{\circ} \mathrm{W}$ \\
\hline 6589 & Bongo & 50 & 6236.05 & 5930.16 \\
6596 & Bongo & 210 & 6223.73 & 5443.88 \\
6597 & Isaacs-Kidd trawl & 220 & 6057.44 & 5339.42 \\
6601 & Isaacs-Kidd trawl & 1432 & 6054.26 & 5121.39 \\
6607 & Isaacs-Kidd trawl & 2250 & 6145.15 & 4846.23 \\
6614 & Isaacs-Kidd trawl & 79 & 6056.11 & 4539.22 \\
6619 & Isaacs-Kidd trawl & 269 & 6220.53 & 5313.44 \\
6653 & Isaacs-Kidd trawl & 2794 & 6225.36 & 5232.6 .2 \\
6655 & Isaacs-Kidd trawl & 2143 & 6217.97 & 5052.18 \\
6684 & Isaacs-Kidd trawl & 1153 & 6035.32 & 5027.47 \\
6687 & Isaacs-Kidd trawl & 634 & 6020.91 & 4835.19 \\
6688 & Isaacs-Kidd trawl & 1765 & 6021.48 & 4827.28 \\
\hline
\end{tabular}

essential (Fe, Mn, $\mathrm{Ni}, \mathrm{Co}, \mathrm{Rb}$ ) and potentially toxic $(\mathrm{Cd}, \mathrm{Cu}, \mathrm{Pb}, \mathrm{Mo}, \mathrm{Zn})$ heavy metals and metalloid As, as well as $\mathrm{Al}$ in the Antarctic krill Euphausia superba collected in 2020 in the Weddell Sea. We intend to identify the variability of trace element concentrations depending on their habitats, to determine the organs of krill with an increased accumulation of heavy metals, to find out whether the age and sex characteristics of individuals affect their distribution patterns.

\section{Materials and Methods}

Sampling of the Antarctic krill Euphausia superba for the determination of elemental compo- sition was carried out in the period from 7 January to 3 March 2020, in cruise 79 of the R/V Akademik Mstislav Keldysh in the northwestern part of the Weddell Sea and adjacent areas [Morozov et al., 2020 (Figure 1). A total of 32 samples was collected at 12 stations (Table 1 ).

In the Northern Powell Basin, the Weddell Front with its relatively high productivity plays an important role in the krill population and growth of individuals originating from different sources: the northwestern Weddell Sea, Bransfield Strait, southern jets of the Antarctic Circumpolar Current (ACC) in the Drake Passage, and the Scotia 


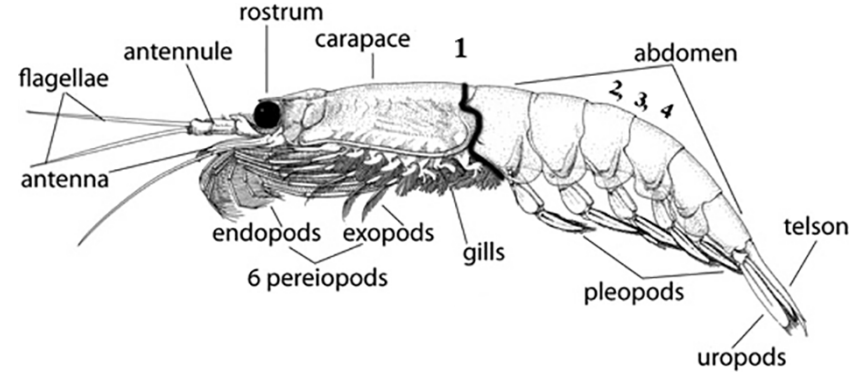

Figure 2. General external morphology of Antarctic krill (total body length around of $60 \mathrm{~mm}$ ). (1) line of separating whole cephalothorax, $(2)$ - whole abdomen, including cuticle and muscle tissue, (3) - cuticle of abdomen with pleopods, (4) - muscle tissue of the abdomen [Springer, 2016].

Sea [Spiridonov et al., 2020] According to hydrological data, above the Antarctic shelf, water is very cold and almost not stratified, the Coastal Current (CC) rounds the Antarctic Peninsula and directs to the southwest into the Bransfield Strait. To the north, there is the Antarctic Slope Front (ASF), and then the Weddell Front (WF), which merges with the ASF in the south. The Warm Deep Water occupies intermediate depths of the open Weddell Sea. At a depth of $600 \mathrm{~m}$, this water is warmer than $1^{\circ} \mathrm{C}$. The upper layer of the Weddell Sea is occupied by Winter Water, which cools in winter and does not warm up deeply in summer, creating a permanent cold intermediate layer. The deep layers of the Weddell Sea are occupied by Weddell Sea Deep Water and Weddell Sea Bottom Water [Fahrbach et al., 2001, Morozov et al., 2020, Thompson and Heywood, 2008.

Krill fishing was carried out at the vessel's speed of 2-3 knots by using oblique catches of the IsaacsKidd multi-depth trawl in the Samyshev-Aseev modification, as well as the Bongo nets. During the work, the maximum depth and duration of fishing were determined based on the analysis of hydrographical conditions at the station. At the end of fishing, several dozen undamaged individuals were selected from the total volume of the sample, followed by sorting into groups based on size, ontogenesis stage, and gender characteristics, in accordance with the accepted methodology [Makarov and Denys, 1981. To prevent possible contamination from the ship, special attention was paid to the preparation of samples: collection, sorting, and dissection of animals was carried out strictly with plastic tools. Emphasis was placed on the size groups prevailing in the catch and the stages of sexual maturity of individuals. The catches included individuals ranging in size from 10 to $60 \mathrm{~mm}$ (Table 2). The predominant species were 20 to $40 \mathrm{~mm}$ long, individuals belonging to the juvenile stage I, in which the sex is not determined, as well as to the stage AII, in which the sex can be determined, but the individual is not yet capable of reproduction. Individuals with sizes from 40 to $60 \mathrm{~mm}$ are the mature females and males (Female/Male), while $R$ is the mixed sample, including both males and females of the juvenile stages. A total of 1395 individuals were analyzed.

The sorted specimens were placed in a refrigerator for a day to seal the tissues, then they were washed several times with distilled water and dissected. According to the anatomical structure of the crustacean (Figure 2), krill specimens were dissected on several components: (1) the whole cephalothorax, including all organs and tissues, (2) the whole abdomen, including cuticle and muscle tissue, (3) the cuticle of the abdomen with pleopods, (4) muscle tissue of the abdomen.

The prepared body parts in plastic Petri dishes were placed in a thermostat for drying at $50-55^{\circ} \mathrm{C}$ for 1-3 days to an air-dry state. Under laboratory conditions, samples (with dry mass varied from 50 to $100 \mathrm{mg}$ ) were previously grounded in a jasper mortar followed by complete chemical decomposition with a mixture of $3 \mathrm{ml}$ of $65 \% \mathrm{HNO}_{3}$ and $2 \mathrm{ml}$ of $50 \% \mathrm{H}_{2} \mathrm{O}_{2}$ in the Teflon bottles with closed lids. Decomposition was carried out in two stages: 1) at room temperature for 12 hours, 2) on a Teflon heating platform at $\leq 70^{\circ} \mathrm{C}$ for 4 hours. The final volume of the solution was $20 \mathrm{ml}$. The concentrations of $\mathrm{Fe}, \mathrm{Mn}$, and $\mathrm{Cu}$ were determined by Atomic Absorption Spectrophotometry (AAS) by use of the KVANT-2NT instrument (Russia), while concentrations of $\mathrm{Ni}, \mathrm{Co}, \mathrm{Zn}, \mathrm{Al}, \mathrm{Mo}, \mathrm{Rb}, \mathrm{Cd}, \mathrm{Pb}$, and As, were determined by inductively coupled plasma mass spectrometry (ICP-MS) on the Agilent 7500 spectrometer (USA). The accuracy of the analysis was controlled using certified standard plankton samples BCR 414, Institute for Reference Material and Measurements, Belgium [European Commission, 2020.

\section{Results and Discussion}

The concentration of metals in the total krill samples $(n=32)$ are listed in Table 3. The 
Table 2. Size and Maturity Stage/Sex Groups of Krill in Selected Samples

\begin{tabular}{lccc}
\hline Station & Number of individuals & Size, mm & Stage/Sex \\
\hline 6589 & 12 & $20-40$ & I \\
6596 & 101 & $10-24$ & I \\
& 34 & $25-41$ & All/ I \\
6597 & 90 & $28-45$ & I \\
& 100 & $25-28$ & R \\
6601 & 46 & $45-55$ & R \\
& 18 & $25-45$ & I \\
6607 & 40 & $10-20$ & Male \\
& 24 & $49-54$ & Male \\
& 37 & $40-48$ & Female \\
& 25 & $49-54$ & Female \\
6614 & 27 & $40-48$ & I \\
& 40 & $25-39$ & Male \\
6619 & 14 & $49-54$ & Female \\
& 10 & $49-54$ & Random \\
6653 & 40 & $29-40$ & I \\
6655 & 113 & $20-30$ & I \\
& 113 & $30-41$ & I \\
6684 & 110 & $10-35$ & I \\
6687 & 100 & $28-37$ & Random \\
& 14 & $38-45$ & Random \\
& 17 & $46-55$ & Female \\
& 120 & $40-55$ & Female \\
& 50 & $40-60$ & Female \\
\hline & 100 & $50-60$ & \\
\end{tabular}

analyzed samples included groups of the small, medium, and large crustaceans with a length of 10 to $60 \mathrm{~mm}$, males, females, and juvenile stages.

The ranges of concentration of each trace element differ significantly, the largest variability ( $\geq 30$ times) is revealed for $\mathrm{Al}, \mathrm{Fe}, \mathrm{Ni}, \mathrm{Mo}, \mathrm{Cd}$, and $\mathrm{Pb}$. Variability of the remaining is smaller, from 2 (As, Zn, Rb) to 10 (Co). The order of increasing average content in total krill samples is as follows: $\mathrm{Al}>\mathrm{Zn}>\mathrm{Fe}>\mathrm{Cu}>\mathrm{Ni}>\mathrm{Mo}>\mathrm{Rb}, \mathrm{As}>\mathrm{Mn}>\mathrm{Cd}>\mathrm{Pb}$ $>$ Co. In the first approximation, this sequence corresponds to average concentrations of dissolved elements in the ocean water [Bruland and Lohan, 2004. The exception is the potentially dangerous metalloid As, whose concentration in ocean water is higher than that of the other trace elements, while its content in total krill specimens is lower than that of $\mathrm{Al}, \mathrm{Zn}, \mathrm{Fe}, \mathrm{Cu}, \mathrm{Ni}$, and $\mathrm{Mo}$. We might assume that this resulted from the biochem- ical self-regulation processes in the krill's tissues. In the ocean water, $\mathrm{Al}$ and $\mathrm{Fe}$ are found predominantly in the suspended phase whose proportion composes 50 and $69 \%$ of total content in ocean water [Gordeev and Lisitzin, 2014]. Given that krill is a non-selective filter-feeder, it is quite natural that $\mathrm{Al}, \mathrm{Zn}$, and $\mathrm{Fe}$, whose content in ocean suspended particles are higher than that of other elements [Bruland and Lohan, 2004], show the highest levels of average concentrations in the krill specimens.

The levels of trace element concentrations listed in Table 3 are similar to the earlier published data in order of decimal values. In the total krill specimens (with various body sizes) sampled in different areas and seasons, the following sequence of increasing concentrations was revealed: $\mathrm{Cu}>\mathrm{Zn}>$ $\mathrm{Fe}>\mathrm{Mn}>\mathrm{Ni} \mathrm{Cd}>\mathrm{Pb}>\mathrm{Hg}$, along with the high bioconcentration coefficients of many metals (BCF up 
Table 3. Trace Element Contents ( $\mathrm{gg} / \mathrm{g}$ dry w.) in Total Samples of Euphausia superba Krill From the Northwestern Weddell Sea

\begin{tabular}{lcccccccccccc}
\hline Values & $\mathrm{Mn}$ & $\mathrm{Fe}$ & $\mathrm{Cu}$ & $\mathrm{Ni}$ & $\mathrm{Zn}$ & $\mathrm{Co}$ & $\mathrm{Cd}$ & $\mathrm{Al}$ & $\mathrm{As}$ & $\mathrm{Pb}$ & $\mathrm{Rb}$ & $\mathrm{Mo}$ \\
\hline Maximal & 6.2 & 288 & 58.1 & 32.4 & 107 & 0.6 & 6.9 & 489 & 5.6 & 1.1 & 6.2 & 16.4 \\
Minimal & 1.3 & 12.7 & 10.7 & 1.0 & 38.3 & $<0.05$ & 0.3 & $<5$ & 2.6 & $<0.02$ & 2.4 & $<0.9$ \\
Average & 2.6 & 54.3 & 32.8 & 9.5 & 63.9 & 0.2 & 1.0 & 96 & 4.1 & 0.4 & 4.3 & 7.9 \\
\hline
\end{tabular}

to $2 \times 10^{4}$ ) [Yamamoto et al., 1987]. Along with the increased average $\mathrm{Cu}$ and Fe contents (18.4 and $17.02 \mathrm{~kg} / \mathrm{g}$ dry w., respectively), the anomalous high Cr contents (up to $18.8 \mu \mathrm{g} / \mathrm{g}$ dry w.), were detected in [Raghunath et al., 2000, not noted in other works. In total krill from the western sector of Antarctica, the average contents ( $\mathrm{kg} / \mathrm{g}$ dry w.) of $\mathrm{Cu}$ (80.5), $\mathrm{Zn}$ (43.5), Fe (28.0), Se (5.80), Ba (3.78), Mn (1.98), As (1.92), Ag (1.71), Ni (0.54), Cr (0.30), Cd (0.29), Pb (0.22) and $\mathrm{Hg}(0.025)$ did not exceed the normalized values [Palmer et al., 1995. Increased average $\mathrm{Cu}$ content compared to other metals has also been observed in [Raghunath et al., 2000. At the same time, the average contents of $\mathrm{Fe}, \mathrm{Mn}, \mathrm{Ni}, \mathrm{Cu}$, and $\mathrm{Zn}$ (Table 3) are 2-3 times higher than those in [Raghunath et al., 2000]. The observed differences can be attributed to the fact that over recent 25 years, the increased melting of icebergs happened, which serve as an important source of iron, since its concentration in iceberg meltwater is much higher than in the dissolved $(<0.2$ microns) and suspended $(<0.2 \mathrm{mi}-$ crons) phases of seawater [De Baar et al., 1995 . Martin et al., 1990, Shaw et al., 2011. Besides, many trace elements are known to be associated with the fine-dispersed phases of suspended and colloidal Fe. As the climate warms, the rates of glacier melting and the meltwater volume increase, that obviously leads to an increase in the supply of labile, bioavailable forms of iron and organic carbon to the polar basins [Hopwood et al., 2017, Lawson et al., 2014, Raiswell et al., 2008.

Generally, contamination of sea by heavy metals can be studied from their concentration in water [Mirzoeva et al., 2020, Morozov and Kolokolova, 2015; in sediments [Krek et al., 2020] or in the tissues of animals. The maximum permissible concentrations (MPC) of potentially toxic elements that are regulated for seafood such as shellfish and crustaceans are as follows ( $\mathrm{kg} / \mathrm{g}$ dry w.): $\mathrm{Pb} 10.0, \mathrm{Cd}$ 2.0, As 2.0, $\mathrm{Cu} 30.0$, and $\mathrm{Zn} 200$ [Crommentuijn et al., 1997. According to our data (Table 3), only As is twice as much compared to the MPC, that by analogy to Mo [Mirzoeva et al., 2020 might result from the influence of water inflow from the areas of polymetallic mining in Chile. The $\mathrm{Cu}$ is at the MPC level, while relatively low $\mathrm{Cd}, \mathrm{Pb}$, and Zn contents in krill indicate the absence of anthropogenic pollution.

\section{Spatial Distribution of Trace Elements in Krill Juveniles}

The specimens of total krill juveniles widely represented in the study site were analyzed for the content of trace elements. The analyzed samples included groups of small krill specimens with a length of 10 to $40 \mathrm{~mm}$, which are mainly in the juvenile I and AI/AII stages of maturity. During the growth period, krill in the juvenile I and II maturity stages intensively feeds, grows, accumulating lipids and chemical elements. The spatial distribution of trace elements in total samples of juvenile krill was considered on the example of three groups of stations (A, B, and C). The stations were grouped based on their different geographical location, sea depth, and hydrography parameters that can affect conditions of the habitat and nutrition of krill. The group A includes coastal stations located close to the South Shetland Islands (SSI), st. 6589 (depth of $50 \mathrm{~m}$ ), and to the South Orkney Islands, st. 6614 (depth of $79 \mathrm{~m}$ ). The group B includes st. 6596 (depth of $210 \mathrm{~m}$ ), st. 6597 depth of $220 \mathrm{~m}$ ), st. 6601 (depth of $1432 \mathrm{~m}$ ), st. 6619 (depth of 269 m), st. 6684 (depth of $1153 \mathrm{~m}$ ), st. 6687 (depth of $634 \mathrm{~m}$ ), st. 6688 (depth of $1765 \mathrm{~m}$ ) located in area influenced by the Coastal Current (CC), Antarctic Slope Front (ASF) in the north-northwestern Powell Basin. The C group includes st. 6607 (depth of $2250 \mathrm{~m}$ ), st. 6653 (depth of $2794 \mathrm{~m}$ ), and st. 6655 

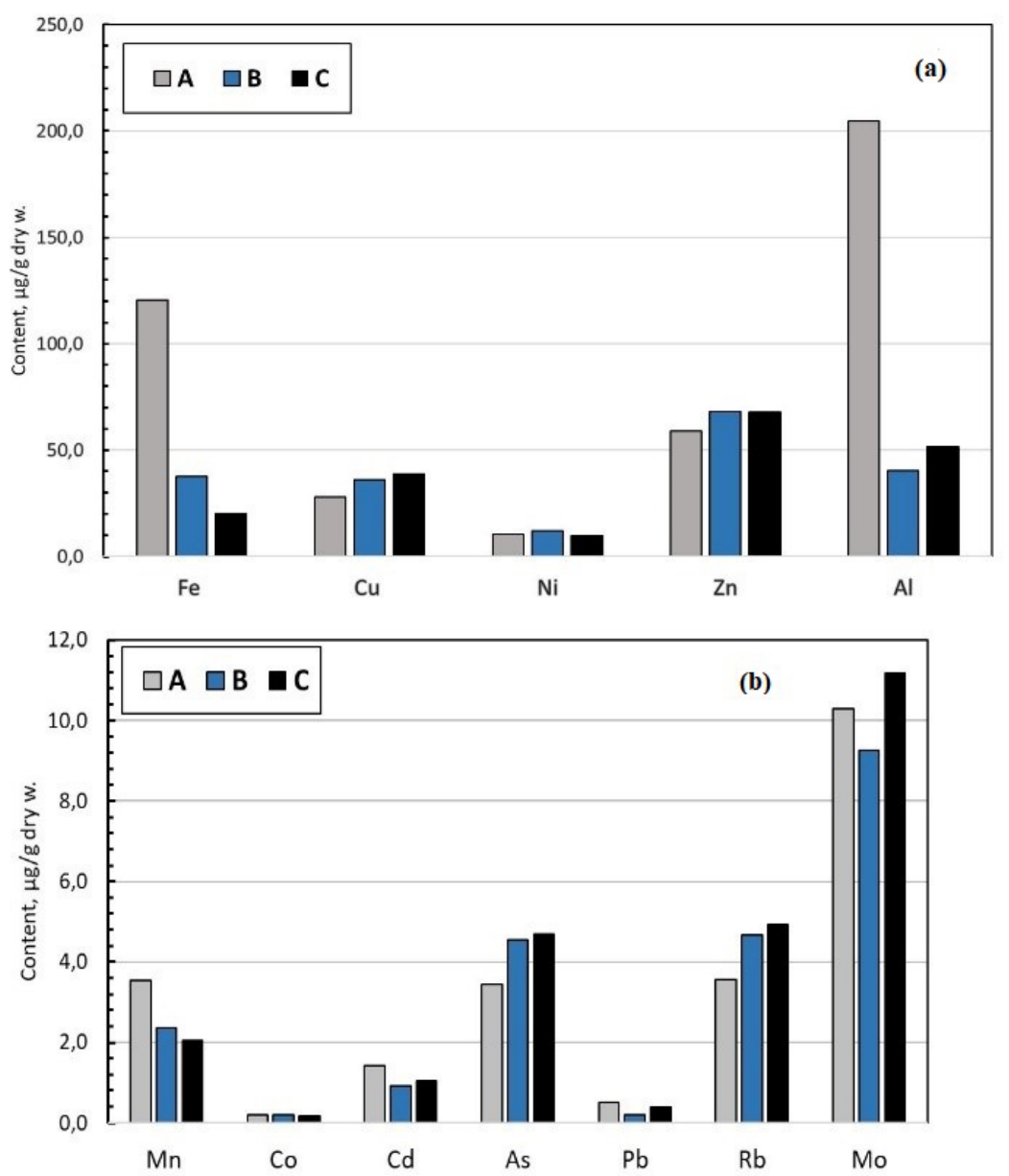

Figure 3. (a,b) - Average concentrations of trace elements $(\mathrm{\mu g} / \mathrm{g})$ in total krill's bodies of juvenile I and I/AII puberty stages in A, B, and C groups of stations in the northwestern Weddell Sea. Group A are shallow-water stations 6589 and 6614 located in vicinity of the South Shetland Islands (SSI) and South Orkney Islands; group B are stations 6596, 6597, 6601, 6619, 6684, and 6688 located in the northern area of the Powell Basin; group $\mathrm{C}$ are stations 6607, 6653, and 6655 in the deep-water area of the Powell Basin.

(depth of $2143 \mathrm{~m}$ ) located in the deep-water area of the Powell Basin, where the Weddell Sea outflow and the Weddell Gyre are the main sources of water masses.

High Fe contents (to $300 \mu \mathrm{g} / \mathrm{g}$ dry w.) in total bodies of juvenile krill was confined to the tip of the Antarctic Peninsula and the South Shetland Islands (SSI), noticeably decreasing in the northern Powell Basin (st. 6601), and over the shelf of the South Orkney Islands (SOI) (st. 6614). In krill specimens from group A stations collected near the islands at sts. 6589 and $6596, \mathrm{Al}$ (which is practically not assimilated by living organisms), Fe, and $\mathrm{Mn}$ to a lesser extent (all three elements are the major elements in the terrigenous suspended par- ticulate matter (SPM)), were detected at a rather high average concentration $(206,120$, and $3.6 \mathrm{\mu g} / \mathrm{g}$ dry w., respectively) (Figure 3 a). Shallow water is known to be enriched in SPM (due to the coastal abrasion processes, while the cyclonic outflow of the Weddell Sea gyre over the shallow shelf regions becomes enriched in sediment-derived $\mathrm{Fe}$, making the intermediate water masses relatively high in Fe [Sanches et al., 2019. The lowest concentrations of $\mathrm{Fe}$ and $\mathrm{Al}$ were found in specimens from group $\mathrm{C}$ (deepwater areas). In the accumulation of $\mathrm{Co}, \mathrm{Cu}, \mathrm{Pb}, \mathrm{Rb}$, and $\mathrm{Zn}$ in krill, there was no significant difference between the three groups of stations. Arsenicum refers to the most dangerous elements for living organisms; while Rb is essential 
for metabolism since it can replace an equivalent amount of $\mathrm{K}$ in various processes (for example, it activates the same enzymes as K). Nevertheless, the distribution pattern of As and Rb is very similar: their lowest contents were detected in shallow water basins of group A, while those with higher concentration in krill were from the deeper regions.

One can see from Table 3 that the maximum $\mathrm{Cd}$ content $(6.9 \mathrm{\mu g} / \mathrm{g}$ dry w.) was detected in krill from the shallow water of SOI (st. 6614). It should be noted that the maximal concentration of dissolved $\mathrm{Cd}(1.17 \mu \mathrm{g} / \mathrm{l})$ was detected in the same area [Mirzoeva et al., 2020. The high $\mathrm{Cd}$ contents (up to $13 \mathrm{\mu g} / \mathrm{g}$ dry w.) in crustaceans from Antarctic regions, which are considered to be rather isolated and have not been related to anthropogenic influences, are regarded as indications of $\mathrm{Cu}$ deficiency [Petri and Zauke, 1993. These authors hypothesized that increased uptake of $\mathrm{Cd}$ might be related to a potential $\mathrm{Cu}$ deficiency due to insufficient selectivity of the uptake process for the essential element $\mathrm{Cu}$.

The elevated Mo content in krill (> $10 \mu \mathrm{g} / \mathrm{g}$ dry w.) was detected at the stations of group A and B, i.e. in both the shallow, and deep-water regions (Figure $3 \mathrm{~b})$. It is seen from the data of [Mirzoeva et al., 2020, that concentarions of dissolved Mo at the same stations were the highest (to $2.5 \mathrm{\mu g} / \mathrm{l}$ ) exceeding the MPC $1.2-2.8$ times. It was attributed to the inflow of certain amount of Mo from the Chilean coastal water exposed to contamination by Mo and other trace elements due to polymetallic mining in Chile.

According to [Mirzoeva et al., 2020], the order of magnitude of descending concentrations of dissolved trace metals is as follows: $\mathrm{Fe}>\mathrm{Zn}>\mathrm{Mo}>\mathrm{Cu}$ $>\mathrm{Ni}>\mathrm{Cd}>\mathrm{Pb}>\mathrm{Co}$, which is rather similar to that of our data for the total krill (see above). However, a comparison of concentrations of dissolved $\mathrm{Mo}, \mathrm{Cu}$, and $\mathrm{Fe}$ [Mirzoeva et al., 2020 with their content in total krill specimens from the same stations, revealed no direct relationship that can be attributed to the extremely complex composition of the size groups in all the studied regions [Spiridonov et al., 2020]. These data suggest that bioaccumulation of heavy metals in krill is a complex nonlinear process that is influenced by many factors including not only their dissolved, but also suspended forms, as well as hydrological and biological characteristics of the habitat.

\section{Distribution of Trace Elements in Krill Specimens of Different Size, Sexual Maturity Stage, and Gender Groups}

A much more complicated relationship appears if, along with the spatial distribution of elements in different regions, we consider specimens of different size, sexual maturity stage, and gender groups. Iron is characterized by the highest accumulation $(80 \mathrm{\mu g} / \mathrm{g}$ dry w.) in juvenile krill of the maturity stage I with a body length of 10-24 mm from the Powel Basin, i.e., the group B of stations with depths of $800-2800 \mathrm{~m}$ (Figure $4 \mathrm{a})$. The reduced Fe contents $(<20 \mu \mathrm{g} / \mathrm{g}$ dry w.) were found in krill of I and AII puberty with a wide range of body length, from $10-35$ to $45-55 \mathrm{~mm}$ from both the Powell Basin and group 3, which includes deepwater stations (more than $3000 \mathrm{~m}$ ). The distribution of $\mathrm{Al}$ is characterized by an increased accumulation (more than $100 \mathrm{\mu g} / \mathrm{g}$ dry w.) in individuals with a body length of 20 to $40 \mathrm{~mm}$ both from the shallow water stations of group A, and the deepwater ones of group C (Figure 4a). Higher concentrations of Mo and Cd are characteristic of the juvenile krill (puberty stage I, with length $<40 \mathrm{~mm}$ ). Maximal $\mathrm{Mo}, \mathrm{Co}$, and $\mathrm{Ni}$ contents were found in specimens with length of 10-20 mm. Unlike these, elevated $\mathrm{Cu}$ accumulation was found in krill of more mature stage AII with length of $45-55 \mathrm{~mm}$. There were no significant differences in the variation of $\mathrm{Zn}, \mathrm{Mn}$, $\mathrm{As}, \mathrm{Rb}$, and $\mathrm{Pb}$ contents in krill specimens of different puberty stages and body sizes (Figure 4b, Figure 4c, Figure 4d).

Comparison of trace metal bioaccumulation in krill of the different gender groups was made for specimens of the same size group (49-54 mm) collected at two stations (6607 and 6614). As can be seen from Figure 4, there were no significant differences between most trace elements, except $\mathrm{Cu}$ and $\mathrm{Pb}$, that have revealed an elevated accumulation in the male specimens compared to the female ones.

\section{Trace Element Partitioning in Selected Organs and Tissues of Krill Euphausia Superba}

The distribution of trace elements was examined in the three main components of the krill body: the 

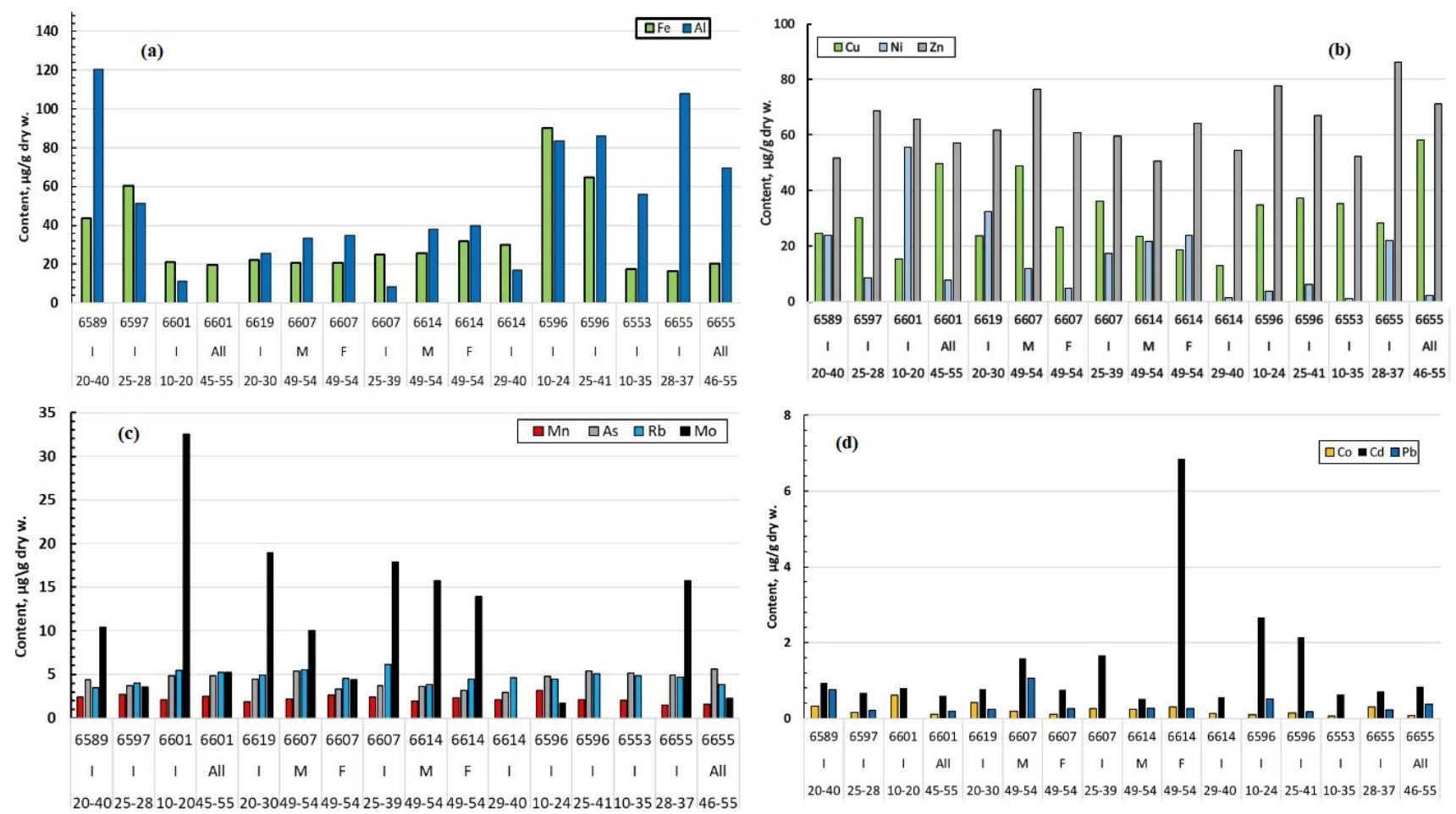

Figure 4. Distribution of trace element concentrations ( $\mu \mathrm{g} / \mathrm{g}$ dry w.) in different size (10-55 mm), sexual maturity stage (I, AII), and gender ( $\mathrm{M}$ - male, F - female) groups of krill sampled at stations in the northwestern Weddell Sea. (a) Fe, Al; (b) Cu, Ni, Zn; (c) Mn, As, Rb, Mo; (d) Co, Cd, Pb.

abdomen muscle, the cuticle of the abdomen, and the cephalothorax (Figure 5).

As can be seen from Figure 5, the concentration of trace elements is different in the selected components of the krill body. An increased accumulation of $\mathrm{Al}, \mathrm{Fe}, \mathrm{Zn}$, and $\mathrm{Cu}$ was found in the cephalothorax. In the abdominal muscles, the content of most elements is reduced compared to other tissues, with the exception of Mo, which is maximum here. In the composition of the cuticle of the abdomen and cephalothorax, the concentrations of most trace elements, except Mo, were significantly higher on average than in muscle tissues. It can be caused by the chemical properties of the biopolymer chitin that forms the cuticle and includes a reactive amino-group and mineral salts (calcium phosphate and carbonate) which are capable of strong binding and retention of $\mathrm{Al}, \mathrm{Fe}, \mathrm{Zn}$, and $\mathrm{Cu}$. There was no significant difference in the $\mathrm{Ni}, \mathrm{Co}, \mathrm{Cd}, \mathrm{As}, \mathrm{Rb}$, and $\mathrm{Pb}$ distribution in the three selected components. The accumulation of trace elements in the chitinous shell contributes to the supply of these elements into the bottom sed- iments due to multiple mass molts of crustaceans throughout the entire life cycle and after it.

\section{Conclusions}

Analysis of trace metals (Al, As, Cd, Co, Cu, $\mathrm{Fe}, \mathrm{Mn}, \mathrm{Mo}, \mathrm{Ni}, \mathrm{Pb}, \mathrm{Rb}$, and $\mathrm{Zn}$ ) in specimens of Antarctic krill Euphausia superba collected in January-February 2020 in the northeastern Weddell Sea, allowed us to draw the following conclusions.

The average contents of $\mathrm{Fe}, \mathrm{Mn}, \mathrm{Ni}, \mathrm{Cu}$, and $\mathrm{Zn}$ in total bodies of juvenile krill were higher compared to those reported in earlier papers, that can be attributed to an enlarged supply of trace elements due to increased iceberg melting over the last 20 years. In the total krill from the shallow water near the SSI and SOI, we found noticeably elevated content of $\mathrm{Fe}$ and $\mathrm{Al}$, the main components of suspended particles, that serve the main krill diet. Unlike these, the elevated Mo contents 

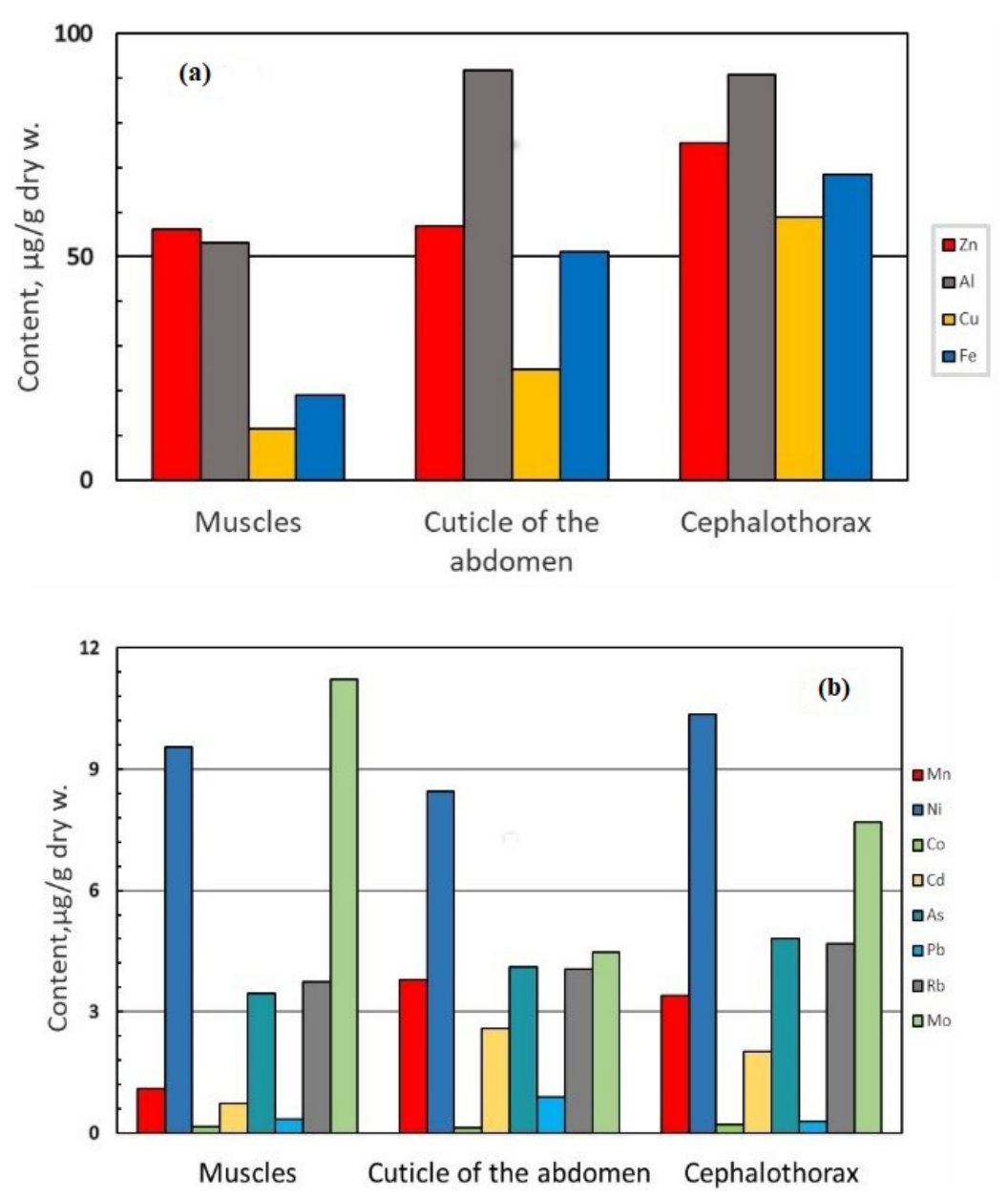

Figure 5. Trace element average contents ( $\mu \mathrm{g} / \mathrm{g}$ dry w.) in the muscles and cuticle of the abdomen, as well as in the cephalothorax of krill Euphausia superba: (a) $\mathrm{Zn}, \mathrm{Al}, \mathrm{Cu}$, Fe; (b) Mn, Ni, Co, Cd, As, Pb, Rb, and Mo.

were detected in krill both from the shallow and deeper regions, following [Mirzoeva et al., 2020], we can attribute it to the anthropogenic factors, namely, the water masses enriched in heavy metals that inflow from the Chilean coastal areas to the Antarctic Peninsula. There were no significant differences in the spatial variation of the other trace elements.

The highest accumulation of $\mathrm{Fe}, \mathrm{Al}, \mathrm{Mo}$, and $\mathrm{Cd}$ were found in the juvenile krill of the maturity stage I with a body length of 10-24 mm from in the Powel Basin, while the rest of elements did not reveal a significant predominant accumulation in certain size group. The elevated contents of $\mathrm{Al}$, $\mathrm{Zn}, \mathrm{Cu}$, and $\mathrm{Fe}$ were found in the cephalothorax, while Mo accumulated mostly in the abdomen muscles. $\mathrm{Ni}, \mathrm{Co}, \mathrm{Cd}, \mathrm{As}, \mathrm{Rb}$, and $\mathrm{Pb}$ did not show a predominant accumulation in certain krill tissues.

The average values of the regulated concentrations of potentially dangerous heavy metals $\mathrm{Zn}$,
$\mathrm{Cd}$, and $\mathrm{Pb}$ were lower than the maximum permissible concentration (MPC) for marine seafood products, which seems to indicate the absence of anthropogenic pollution in the krill samples studied. The average content $\mathrm{Cu}$ was found to be at the MPC level (despite high $\mathrm{Cu}$ production in Chile), while that of As was twice as much compared to the MPC, that similarly to Mo can be attributed to the influence of anthropogenic factors.

Data availability statement. The datasets generated for this study are available on request to the corresponding author.

Funding. This work was supported by the Science and Education Ministry of Russian Federation, State task no. 0128-2019-0008, chemical analysis was supported by Russian Science Foundation, project no. 19-17-00234. 
Acknowledgments. Authors would like to thank our colleagues and crew of cruise for their assistance provided during the cruise $79 \mathrm{R} / \mathrm{V}$ Akademik Mstislav Keldysh. Authors are grateful to Prof. Eugene Morozov (Shirshov Institute of Oceanology RAS) for valuable consultation on hydrology in the study site. Thanks to Dr. D. Starodymova (IO RAS) for performing the ICPMS analysis. This work is dedicated to the memory of the remarkable Professor Vasily A. Spiridonov, who died prematurely in December 2020.

\section{References}

Bizikov, V. A., K. V. Shust (2007), History of the study and development of Antarctic krill reserves, prospects for its fishing by the domestic fleet, Trydu VNIRO, 147, 11-26.

Boyd, P. W., A. C. Crossley, D. R. Di Tullio (2001), Control of phytoplankton growth by iron supply and irradiance in the subantarctic Southern Ocean: experimental results from SAZ Project, Journal of Geophysical Research, 31, 31,573-31,578.

Bowen, H. J. M. (1988), Trace elements in biological samples, Techniques and Instrumentation in Analytical Chemistry (Vol. 8), R. Cesareo (ed.) p. 1-17, Elsevier, Amsterdam; Oxford; New York; Tokyo. Crossref

Bruland, K. W., $\quad$ M. C. Lohan (2004), Controls of trace metals in sea water, Treatise on Geochemistry, H. D. Holland and K. K. Turekian (eds.), Vol. 6 p. 23-47, Elsevier, Amsterdam. Crossref

Bykova, V. M., (ed.) (2001), Antarctic Krill: A handbook, 207 pp. VNIRO Publishing House, Moscow.

Crommentuijn, T., M. D. Polder, E. J. van de Plassche (1997), Maximum Permissible Concentration and Negligible Concentration for Metals, Taking Background Concentration into Account, 260 pp. National Institute of Public Health and the Environment, Bilthoven, Netherlands. ((RIVM Report no. 601501001$)$ )

De Baar, H. J. W., J. T. M. De Jong, et al. (1995), Importance of iron for plankton blooms and carbon dioxide drawdown in the South Ocean, Nature, 373, 412-415, Crossref

Demina, L. L. (2015), Quantitative assessment of the role of living matter in the geochemical migration of trace elements in the ocean, Geochemistry Intern., 3, 234-251, Crossref

Duprat, L.P. A. M., G. R. Bigg, D. J. Wilton (2016), Enhanced Southern Ocean marine productivity due to fertilization by giant icebergs, Nature Geoscience, 9, No. 3, 219-221, (ISSN 1752-0894) Crossref

European Commission (2020), Certified Reference Materials, Catalogue of Directorate General, p. 106, Joint Res. Centre of European Commission, Bel- gium. (https://crm.jrc.ec.europa.eu/graph ics/cms_ docs/rm_catalogue.pdf)

Fahrbach, E., M. Hoppema, et al. (2001), Flow of bottom water in the northwestern Weddell Sea, Journal of Geophysical Research, 106, No. C2, 27612778, Crossref

Fogwill, C. J., C. S. M. Turney, L. Menviel (2020), Southern Ocean carbon sink enhanced by sea-ice feedbacks at the Antarctic Cold Reversal, Nature Geoscience, 13, 489-497, Crossref

Fowler, S. W. (1977), Trace elements in zooplankton particulate products, Nature, 269, 51-53, Crossref

Fuentes, V., G. Alurralde, et al. (2016), Glacial melting: An overlooked threat to Antarctic krill, Scientific Reports, 6, No. art. no. 27,234, Crossref

Gordeev, V. V., A. P. Lisitzin (2014), Geochemical interaction between the freshwater and marine hydrospheres, Russian Geology and Geophysics, 55, 562-581, Crossref

Holm-Hansen, O., M. Kahru, C. D. Hewes (2005), Deep chlorophyll-a maxima in pelagic Antarctic waters in relation to bathymetric features and dissolved iron concentrations, Marine Ecology Progress Series, 297, 71-81, Crossref

Hopwood, M. J., C. Cantoni, et al. (2017), The heterogeneous nature of Fe delivery from melting icebergs, Geochemistry Perspective Letters, 3, 200209, Crossref

Hutchins, D. A. (1995), Iron and the marine phytoplankton community, Progress in Physiological Research, D. J. Chapman, and F. E. Round (eds.), Vol. 11 p. 1-48, Biopress, Bristol.

Kawaguchi, S., S. Nicol (2007), Learning about Antarctic krill from the fishery, Antarctic Science, 19, No. 2, 219-230, Crossref

Krek, A., V. Krechik, et al. (2020), The role of fluids in the chemical composition of the upper holocene sediment layer in the Russian sector of the South-East Baltic, Russ. J. Earth Sci., 20, ES6006, Crossref

Lawson, E. C., J. L. Wadham, et al. (2014), Greenland Ice Sheet exports labile organic carbon to the Arctic oceans, Biogeosciences, 11, 4015-4028, Crossref

Lisitzin, A. P. (2004), Sedimentary matter fluxes, natural filters, and sediment systems of the "living ocean", Russian Geology and Geophysics, 45, No. 1, 15-48.

Makarov, R. R., C. J. Denys (1981), Stages of sexual maturity of Euphausia superba, Dana BIOMASS Handbook, No. 11, 1-13.

Martin, J. H., G. A. Knauer (1973), The elemental composition of plankton, Geochim. Cosmochim. Acta, 37, 1639-1653, Crossref

Martin, J. H., S. E. Fitzwater, R. M. Gordon (1990), Iron deficiency limits phytoplankton growth in Antarctic waters, Global Biogeochemical Cycles, 4, 5-12.

Mirzoeva, N. Yu., N. N. Tereshchenko, et al. (2020), Heavy metals in surface water of the Atlantic sector of the Antarctic during the cruise 79 of the R/V "Aka- 
demic Mstislav Keldysh", Marine Biological Journal, 5, No. 4, 56-68, Crossref

Monin, A. S., A. P. Lisitsyn, (eds.) (1983), Biogeochemistry of the Ocean, 368 pp. Nauka, Moscow. (in Russian)

Morozov, E. G., V. A. Spiridonov, et al. Investigations of the ecosystem in the Atlantic sector of Antarctica (Cruise 79 of the R/V "Akademik Mstislav Keldysh"), Oceanology, 60, No. 5, 721723, Crossref

Morozov, E. G., A. V. Kolokolova (2015), Physical and chemical properties of seawater over the slopes of the northern part of the Mid-Atlantic Ridge, Russ. J. Earth. Sci., 15, ES2001, Crossref

Nicol, S., M. Stolp, O. Nordstrom (1992), Change in the gross biochemistry and mineral content accompanying the moult cycle in the Antarctic krill Euphausia superba, Marine Biology, 113, 201-209, Crossref

Palmer-Locarnini, S. J., B. J. Presley (1995), Trace element concentrations in Antarctic krill, Euphausia superba, Polar Biology, 15, 283-288, Crossref

Petri, G., G. P. Zauke (1993), Trace metals in crustaceans of the Antarctic Ocean, AMBIO Journal of the Human Environment, Research and Management, (Sweden), 22, No. 8, 529-536.

Raghunath, M. R., T. V. Sankar, et al. (2000), Biochemical investigations on Antarctic krill Euphausia superba, Fishery Technology, 200, No. 37(1), 19-24. (http://hdl.handle.net/123456789/132)

Raiswell, R., L. G. Benning, et al. (2008), Bioavailable iron in the Southern Ocean: the significance of the iceberg conveyor belt, Geochemical Transactions, 9, Crossref

Samyshev, E. Z., N. I. Minkina (2019), Coastal ecosystem contamination by heavy metals as an indicator of climate change in Antarctica, Journ. Computational and Theoretical Nanoscience, 16, No. 1, 228-236, Crossref

Sanchez, N., C. S. Reiss, et al. (2019), WeddellScotia confluence effect on the iron distribution in waters surrounding the South Shetland (Antarctic Peninsula) and South Orkney (Scotia Sea) Islands during the Austral Summer in 2007 and 2008, Frontiers in Marine Science, 6, No. 771, Crossref

Shaw, T. J., R. Raiswell, et al. (2011), Input, composition and potential impact of terrigenous material from free-drifting icebergs, Deep-Sea Research, II, 58, 1376-1383, Crossref

Siegel, V., J. L. Watkins (2016), Distribution, biomass and demography of Antarctic Krill, Euphau- sia superba, Advances in Polar Ecology, Siegel $V$. (ed.), Vol. 1, Biology and Ecology of Antarctic Krill p. 21-100, Crossref

Siegel, D. A., E. Fields, K. O. Buesseler (2007), A bottom-up view of the biological pump: modeling statistical funnels above ocean sediment traps, DeepSea Research Part 1, 55, No. 1, 108-127, Crossref Sologub, D. (2015), Hydroacoustic Observation of Antarctic Krill (Euphausia superba) in Atlantic Sector of Antarctica During 2010/11 season, Trudy VNIRO, 55, Crossref

Spiridonov, V. A. (1996), A scenario of the Late-Pleistocene-Holocene changes in the distributional range of Antarctic krill, Euphausia superba, Marine Ecology, 17, No. 1-3, 519-541, Crossref

Spiridonov, V. A., A. K. Zalota, et al. (2020), Composition of population and transport of juveniles of Antarctic krill in Powell Basin region (northwestern Weddell Sea) in January 2020, Trudy VNIRO, 181, $33-51$, Crossref

Springer (2016), Advances in Polar Ecology, Springer International Publishing, Switzerland. (Libr. of Congress Control Numb. 2016945250)Crossref

Sullivan, C., K. Arrigo, et al. (1993), Distributions of phytoplankton blooms in the Southern Ocean, Science, 262, 1832-1837, Crossref

Sunda, W. G. (1989), Trace metal interactions with marine phytoplankton, Biolog. Oceanography, 6, 411-442.

Thompson, A. F., K. J. Heywood (2008), Frontal structure and transport in the northwestern Weddell Sea, Deep-Sea Res. I, 55, 1229-1251, Crossref

Trathan, P. N., S. L. Hill (2016), The importance of krill predation in the Southern Ocean, Advances in Polar Ecology, V. Siegel (ed.), Vol. 1, Biology and Ecology of Antarctic Krill p. 321-350, Crossref

Twining, B. S., S. B. Baines (2013), The trace metal composition of marine phytoplankton, Annu. Rev. Mar. Sci., 5, 191-215, Crossref

Yamamoto, Y., K. Honda, R. Tatsukawa (1987), Heavy metal accumulation in Antarctic krill Euphausia Superba, Proc. NIPR Symp. on Polar Biol., 1, 198-204.

Corresponding author:

A. S. Solomatina, Shirshov Institute of Oceanology, Russian Academy of Sciences, 36 Nakhimovskii prospect, 117997 Moscow, Russia. (blackmaple@yandex.ru) 